\title{
Veranderingen in de omvang en samenstelling van de beroepsbevolking als gevolg van de overstap op de ILO-definitie van de beroepsbevolking
}

Citation for published version (APA):

Bijlsma, I., Dijksman, S., Fouarge, D., Künn-Nelen, A. C., \& Poulissen, D. (2015). Veranderingen in de omvang en samenstelling van de beroepsbevolking als gevolg van de overstap op de ILO-definitie van de beroepsbevolking. ROA. ROA Technical Reports No. 006 https://doi.org/10.26481/umarot.2015006

Document status and date:

Published: 01/01/2015

DOI:

10.26481/umarot.2015006

Document Version:

Publisher's PDF, also known as Version of record

Please check the document version of this publication:

- A submitted manuscript is the version of the article upon submission and before peer-review. There can be important differences between the submitted version and the official published version of record.

People interested in the research are advised to contact the author for the final version of the publication, or visit the DOI to the publisher's website.

- The final author version and the galley proof are versions of the publication after peer review.

- The final published version features the final layout of the paper including the volume, issue and page numbers.

Link to publication

\footnotetext{
General rights rights.

- You may freely distribute the URL identifying the publication in the public portal. please follow below link for the End User Agreement:

www.umlib.nl/taverne-license

Take down policy

If you believe that this document breaches copyright please contact us at:

repository@maastrichtuniversity.nl

providing details and we will investigate your claim.
}

Copyright and moral rights for the publications made accessible in the public portal are retained by the authors and/or other copyright owners and it is a condition of accessing publications that users recognise and abide by the legal requirements associated with these

- Users may download and print one copy of any publication from the public portal for the purpose of private study or research.

- You may not further distribute the material or use it for any profit-making activity or commercial gain

If the publication is distributed under the terms of Article 25fa of the Dutch Copyright Act, indicated by the "Taverne" license above, 


\section{Veranderingen in de omvang en samenstelling van de beroepsbevolking als gevolg van de overstap op de ILO- definitie van de beroepsbevolking}

Ineke Bijlsma

Sander Dijksman

Didier Fouarge

Annemarie Künn-Nelen

Davey Poulissen

\section{ROA Technical Report}

ROA-TR-2015/6

Researchcentrum voor Onderwijs en Arbeidsmarkt | ROA

Research Centre for Education and the Labour Market | ROA 


\title{
Veranderingen in de omvang en samenstelling van de beroepsbevolking als gevolg van de overstap op de ILO- definitie van de beroepsbevolking
}

\author{
Ineke Bijlsma \\ Sander Dijksman \\ Didier Fouarge \\ Annemarie Künn-Nelen \\ Davey Poulissen
}

ROA-TR-2015/6

October 2015

Research Centre for Education and the Labour Market Maastricht University

P.O. Box 616, 6200 MD Maastricht, The Netherlands

$\mathrm{T}+31433883647 \mathrm{~F}+31433884914$

secretary-roa-sbe@maastrichtuniversity.nl www.roa.nl 


\section{Inhoud}

1 Inleiding 2

2 Belangrijkste verschillen in (de operationalisatie van) de oude en nieuwe definitie van de beroepsbevolking

3 Verschuivingen in werkgelegenheid als gevolg van overschakeling op nieuwe definitie

6

3.1 Aantal werkenden, werklozen en het werkloosheidspercentage onder beide definities

3.2 Samenstelling van het aantal werkenden naar opleidingsniveau, leeftijd en geslacht

3.3 Opleidingsniveau werkenden 10

3.4 Aandeel werkende 55-plussers 12

3.5 Aandeel werkende jongeren 14

3.6 Aandeel werkende vrouwen 17

3.7 Beroepsgroepen met sterkste toename in aantal werkenden 
Met ingang van 2015 hanteert het CBS een andere definitie voor het meten van de omvang van de beroepsbevolking. Waar voorheen gebruik werd gemaakt van een definitie die was vastgesteld door de Centrale Commissie voor de Statistiek (CCS), wordt vanaf 2015 gebruik gemaakt van de definitie van de International Labour Organisation (ILO). Vorige edities van het ROArapport De arbeidsmarkt naar opleiding en beroep waren net als de CBScijfers destijds gebaseerd op de CCS-definitie, terwijl in het rapport De arbeidsmarkt naar opleiding en beroep tot 2020 voor het eerst gebruik zal worden gemaakt van de ILO-definitie voor het bepalen van de omvang van de beroepsbevolking en aanverwante begrippen zoals het werkloosheidspercentage. De ILO-definitie geldt internationaal als standaard voor het bepalen van de beroepsbevolking en wordt daarom vaak de internationale definitie voor de beroepsbevolking genoemd. De CCS-definitie is een Nederlandse definitie van de beroepsbevolking die ook wel bekend staat als de nationale definitie van beroepsbevolking. Laatstgenoemde definitie wijkt op een aantal punten sterk af van de internationale ILO-definitie (zie paragraaf 2). Het belangrijkste verschil van de nationale definitie ten opzichte van de internationale definitie betreft het urencriterium. De nationale definitie van de beroepsbevolking omvat alleen mensen die substantieel werk hebben of willen hebben, waarbij de grens op 12 uur per week is gelegd. ${ }^{2}$ Een tweede verschil betreft het feit dat het $C B S$ in de operationalisatie van de nationale definitie alleen personen in de leeftijd 15 tot en met 64 jaar tot de beroepsbevolking rekent terwijl bij de operationalisatie van de internationale definitie een ruimere leeftijdsgrens wordt gehanteerd, namelijk alle personen in de leeftijd 15 tot en met 74 jaar. Daarnaast verschillen de nationale en internationale definities op een aantal andere punten als het gaat om de afbakening van de groep werklozen (wel of niet willen werken en de beschikbaarheids- en zoekcriteria). $^{3}$

Dit rapport is tot stand gekomen als onderdeel van het Project Onderwijs-Arbeidsmarkt (POA).

2 Zie bijvoorbeeld Bierings, H.B.A., Imbens, J.C.M. \& Van Bochove, C.A. (1991). De definitie van de beroepsbevolking. Supplement Sociaal-Economische Maandstatistiek, 91(1).

3 Zie Souren, M. (2015). De Nederlandse beroepsbevolking volgens de internationale definitie. Tijdschrift voor Arbeidsvraagstukken, 31(1), 62-69. 
Aangezien er verschillende uitgangspunten aan de oude en de nieuwe definities van de beroepsbevolking ten grondslag liggen, leiden de beide definities tot verschillende cijfers over de omvang van de beroepsbevolking en daarmee dus ook tot verschillende cijfers voor aanverwante begrippen zoals de werkloosheid. Al met al resulteert de overgang van de nationale naar de internationale definitie in een toename van de werkzame beroepsbevolking van 7,1 miljoen naar 8,2 miljoen en in een afname van het aantal werklozen van 700 duizend naar 660 duizend in 2014 .

Het doel van dit technisch rapport is om een meer algemeen beeld te schetsen van de gevolgen die de overgang op de nieuwe definitie heeft voor de omvang en samenstelling van de werkzame beroepsbevolking. Hierbij wordt ook aandacht geschonken aan de effecten voor verschillende beroepsgroepen.

In de volgende paragraaf wordt eerst gekeken naar de verschillen in (de operationalisatie van) de oude en nieuwe definitie van de beroepsbevolking, waarna in paragraaf 3 de gevolgen voor zowel het aantal als de samenstelling van de groep werkenden voor verschillende beroepsgroepen zullen worden geanalyseerd. 
De belangrijkste verschillen tussen de oude en de nieuwe definitie van de beroepsbevolking zijn weergeven in figuur 1 . Het voornaamste verschil zit in het aantal uren dat iemand werkt of wil werken. De beroepsbevolking bestaat in de oude definitie enkel uit personen die ten minste 12 uur per week betaalde arbeid verrichten (werkzame beroepsbevolking) of willen verrichten (werkloze beroepsbevolking). In de nieuwe definitie geldt daarentegen dat personen al onderdeel uitmaken van de beroepsbevolking op het moment dat ze minimaal 1 uur per week betaalde arbeid verrichten (werkzame beroepsbevolking) of willen verrichten (werkloze beroepsbevolking). Naast dit verschil werden er in de operationalisatie van de oude definitie door het CBS enkel personen meegenomen uit de leeftijdscategorie 15 tot en met 64 jaar, terwijl het CBS in de operationalisatie van de nieuwe definitie meestal uitgaat van de grotere groep 15-74 jarigen.

In de oude definitie van de beroepsbevolking werd de nadruk gelegd op arbeid als een sociaal verschijnsel, terwijl in de nieuwe definitie van de beroepsbevolking de nadruk sterker ligt op de totale inzet van de productiefactor arbeid. De benadering van arbeid als sociaal verschijnsel had een duidelijk voordeel voor het CBS. Een dergelijke benadering bleek namelijk niet alleen bruikbaar voor de arbeidsstatistieken, maar ook voor andere sociale statistieken. De 12-uursgrens werd hierbij gekozen omdat vanaf anderhalve dag per week een meerderheid van de mensen aangeeft dat werk hun belangrijkste bezigheid is en gezien het feit dat het (willen) werken van een substantieel aantal uren centraal staat in de oude definitie. $^{4}$

Een voordeel van de nieuwe definitie is dat statistieken zoals werkloosheidcijfers makkelijker internationaal te vergelijken zijn. Bovendien ligt de verruiming van de leeftijdsafbakening bij de operationalisatie van de nieuwe definitie voor de hand vanuit het oogpunt

${ }^{4}$ Zie Janssen, B., \& Dirven, H-J. (2015). Werkloosheid: Twee afbakeningen. Sociaaleconomische Trends, februari 2015. 
van de wettelijke veranderingen in de AOW-leeftijd en de daarmee gepaard gaande toename in verwachtte pensioenleeftijd ${ }^{5}$ en toename in arbeidsdeelname onder de groep 65-74 jarigen.

\section{Figuur 1}

Belangrijkste verschillen in (de operationalisatie van) de oude en nieuwe definitie van de beroepsbevolking. ${ }^{6}$

\section{De beroepsbevolking (oude definitie)}

Bestaat uit alle personen (15 t/m 64 jaar)* die:

- Ofwel minimaal 12 uur per week werken

- Ofwel werk hebben geaccepteerd waardoor ze ten minste

12 uur per week zullen gaan werken

- Ofwel actief op zoek zijn naar (en beschikbaar zijn voor)

werk voor ten minste 12 uur per week

\section{$\rightarrow \quad$ Werkzame beroepsbevolking}

Bestaat uit alle personen die ten minste

12 uur per week betaald werken

\section{$>\quad$ Werkloze beroepsbevolking}

Bestaat uit alle personen die op dit moment geen betaald werk hebben en ten minste $\mathbf{1 2}$ uur per week willen werken of werk hebben geaccepteerd waardoor ze ten minste $\mathbf{1 2}$ uur per week zullen gaan werken

\author{
De beroepsbevolking (nieuwe definitie) \\ Bestaat uit alle personen (15 t/m 74)* die: \\ - Ofwel minimaal 1 uur per week werken \\ - Ofwel werk hebben geaccepteerd waardoor ze ten minste \\ 1 uur per week zullen gaan werken \\ - Ofwel actief op zoek zijn naar (en beschikbaar zijn voor) \\ werk voor ten minste 1 uur per week

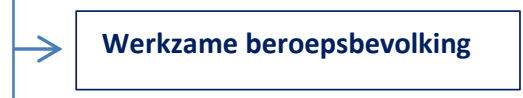 \\ Bestaat uit alle personen die ten minste \\ 1 uur per week betaald werken of dit binnen de \\ komende drie maanden zullen gaan doen

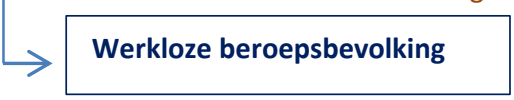 \\ Bestaat uit alle personen die momenteel geen werk \\ hebben en ten minste $\mathbf{1}$ uur per week willen werken \\ of werk hebben geaccepteerd waardoor ze over drie \\ maanden (of later) minimaal 1 uur per week zullen \\ gaan werken
}

* Hoewel in beide definities van de beroepsbevolking formeel geen leeftijdscriteria zijn opgenomen, wordt in CBS-publicaties normaliter uitgegaan van de in de figuur beschreven leeftijdscriteria.

5 Grip, A. de, Fouarge, D. \& Montizaan, R. (2013). How sensitive are individual retirement expectations to raising the retirement age? De Economist, 161(3), 225-251.

6 Voor een uitgebreider overzicht van de verschillen tussen de twee definities, waaronder de verschillen in de beschikbaarheids- en zoekcriteria, zie de referentie in voetnoot 4. 


\subsection{Aantal werkenden, werklozen en het werkloosheidspercentage onder beide definities}

De omvang van de beroepsbevolking in het meest recente jaar waarvoor informatie beschikbaar is (2014) valt $13,1 \%$ hoger uit onder de nieuwe definitie vergeleken met de oude definitie ( 8,9 miljoen i.p.v. 7,8 miljoen). Zoals is te zien in figuur 2 blijken beide definities van de beroepsbevolking een vergelijkbare ontwikkeling over tijd te laten zien van zowel de werkzame beroepsbevolking (linker as) als de werkloze beroepsbevolking (rechter as). Een stijging of daling van het aantal werkenden of werklozen in de ene definitie gaat over het algemeen immers gepaard met eenzelfde beweging in het aantal werkenden of werklozen volgens de andere definitie. ${ }^{7}$ Wel is het zo dat de omvang van de werkzame beroepsbevolking hoger uitvalt onder de nieuwe definitie van de beroepsbevolking, terwijl de werkloze beroepsbevolking juist lager uitvalt onder de nieuwe definitie. Bovendien blijkt er over tijd sprake te zijn van een lichte, maar statistisch significante, divergentie in het aantal werkenden onder beide definities van de beroepsbevolking. In de periode 2003-2014 nam het verschil tussen het aantal werkenden onder de nieuwe en de oude definitie van de beroepsbevolking daardoor jaarlijks met gemiddeld $0,2 \%$ van het totaal aantal werkenden in 2014 (volgens de nieuwe definitie) toe. Deze lichte divergentie is onder andere het resultaat van de toenemende arbeidsparticipatie van ouderen (de nieuwe definitie neemt ook personen ouder dan 64 mee $)^{8}$ en een toename van de hoeveelheid deeltijdwerk in recente jaren (de nieuwe definitie neemt ook banen van minder dan 12 uur mee). ${ }^{9}$

Naast de ontwikkeling van het totaal aantal werkenden en werklozen onder beide definities van de beroepsbevolking is ook gekeken naar de ontwikkeling van het aantal werkenden binnen alle 114 beroepsgroepen die

Deze sterke samenhang uit zich o.a. in een correlatiecoëfficiënt van 0,9.

8 De bruto arbeidsparticipatie van ouderen (65 tot 75 jaar) steeg van 5,6\% in 2003 naar 11,7\% in 2014 en de netto arbeidsparticipatie steeg in diezelfde periode van 5,5\% naar $11 \%$ (CBS Statline).

9 In 2003 werkte 43,3\% procent van de werkenden in deeltijd (d.w.z. betaald werk van gemiddeld minder dan 35 uur per week), tegenover 48,6\% in 2014 (CBS Statline). 
worden onderscheiden in de Beroepenindeling ROA-CBS 2014 (BRC 2014). ${ }^{10}$ Uit deze analyse blijkt dat er ook binnen de afzonderlijke beroepsgroepen sprake is van een vergelijkbare ontwikkeling over tijd in het aantal werkenden onder beide definities. ${ }^{11}$ Ook in de afzonderlijke beroepsgroepen geldt echter relatief vaak (voor 52 van de 114 beroepsgroepen) dat er een lichte, maar statistisch significante divergentie over tijd in het aantal werkenden volgens beide definities van de beroepsbevolking optreedt. ${ }^{12}$

De toegenomen omvang van de werkzame beroepsbevolking in combinatie met de afgenomen omvang van de werkloze beroepsbevolking leidt uiteraard ook tot een lager werkloosheidspercentage onder de nieuwe definitie van de beroepsbevolking. Aangezien de ontwikkelingen van zowel de werkzame als de werkloze beroepsbevolking volgens beide definities van de beroepsbevolking een vergelijkbare ontwikkeling over tijd vertonen, is de ontwikkeling van het werkloosheidspercentage onder beide definities vergelijkbaar (zie figuur 3). Voor wat betreft de ontwikkeling van deze arbeidsmarktindicatoren leveren beide definities van de beroepsbevolking dus hetzelfde beeld op. Dit geldt echter niet voor het absolute aantal werkenden, werklozen en het de hoogte van het werkloosheidspercentage.

${ }^{10}$ Werklozen maken uiteraard geen onderdeel uit van een specifieke beroepsgroep waardoor de ontwikkeling van het aantal werklozen niet kan worden uitgesplitst naar beroepsgroep.

${ }^{11}$ Voor bijna alle groepen geldt dat er een correlatiecoëfficiënt hoger dan 0,8 (en dus een erg sterke samenhang) wordt gevonden tussen het aantal werkenden volgens beide definities. Uitzonderingen hierop zijn de laders, lossers en vakkenvullers $(r=0,54)$, schoonmakers $(r=0,64)$ en vuilnisophalers en dagbladenbezorgers $(r=0,67)$, waarvoor de correlatiecoëfficiënten nog steeds als relatief sterk kunnen worden beschouwd.

12 Een lichte, maar statistisch significante convergentie in het aantal werkenden blijkt daarentegen slechts op te treden in 5 van de 114 beroepsgroepen. 


\section{Figuur 2}

Ontwikkeling van de werkzame en werkloze beroepsbevolking onder de oude en nieuwe definitie van de beroepsbevolking

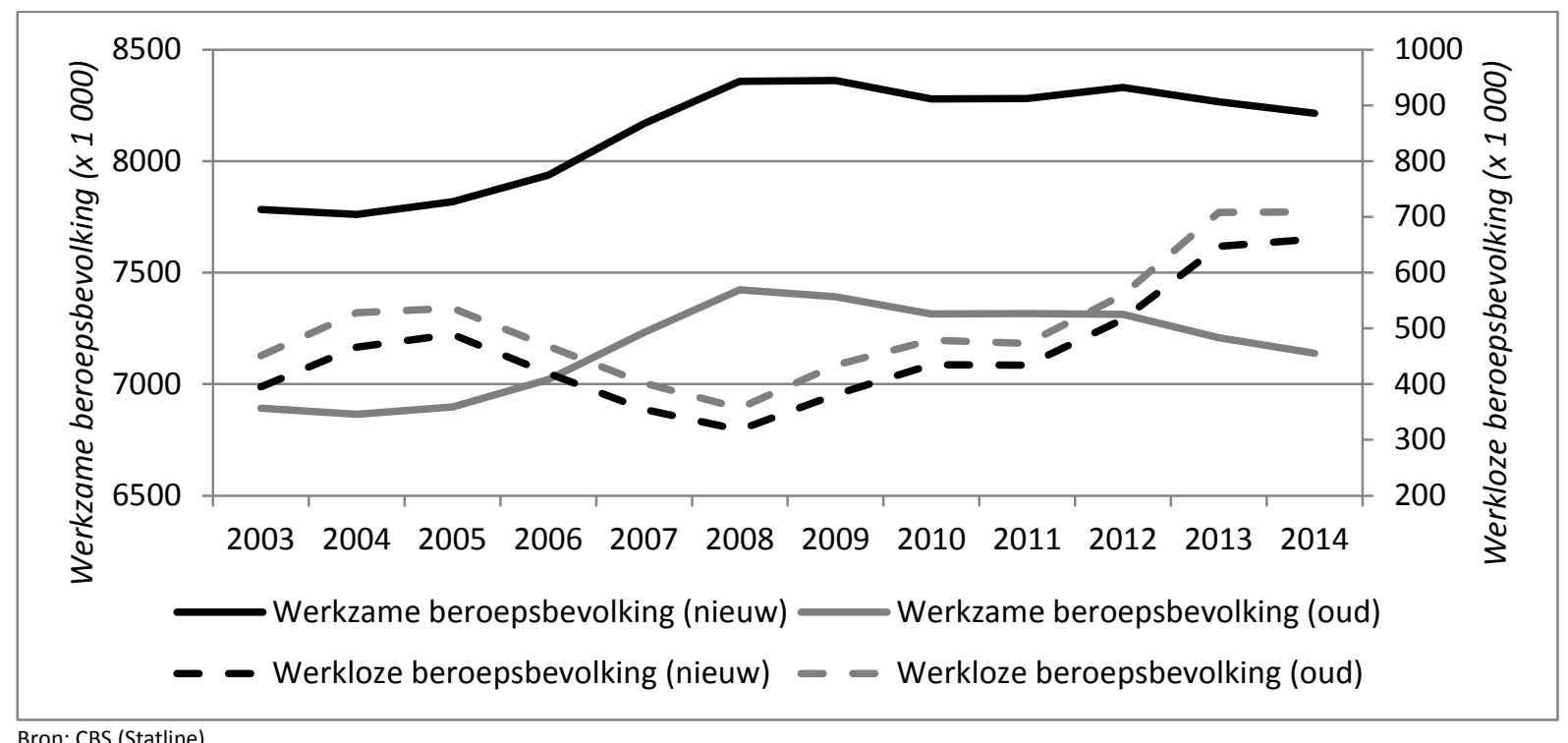

Figuur 3

Ontwikkeling van het werkloosheidspercentage onder de oude en nieuwe definitie van de beroepsbevolking

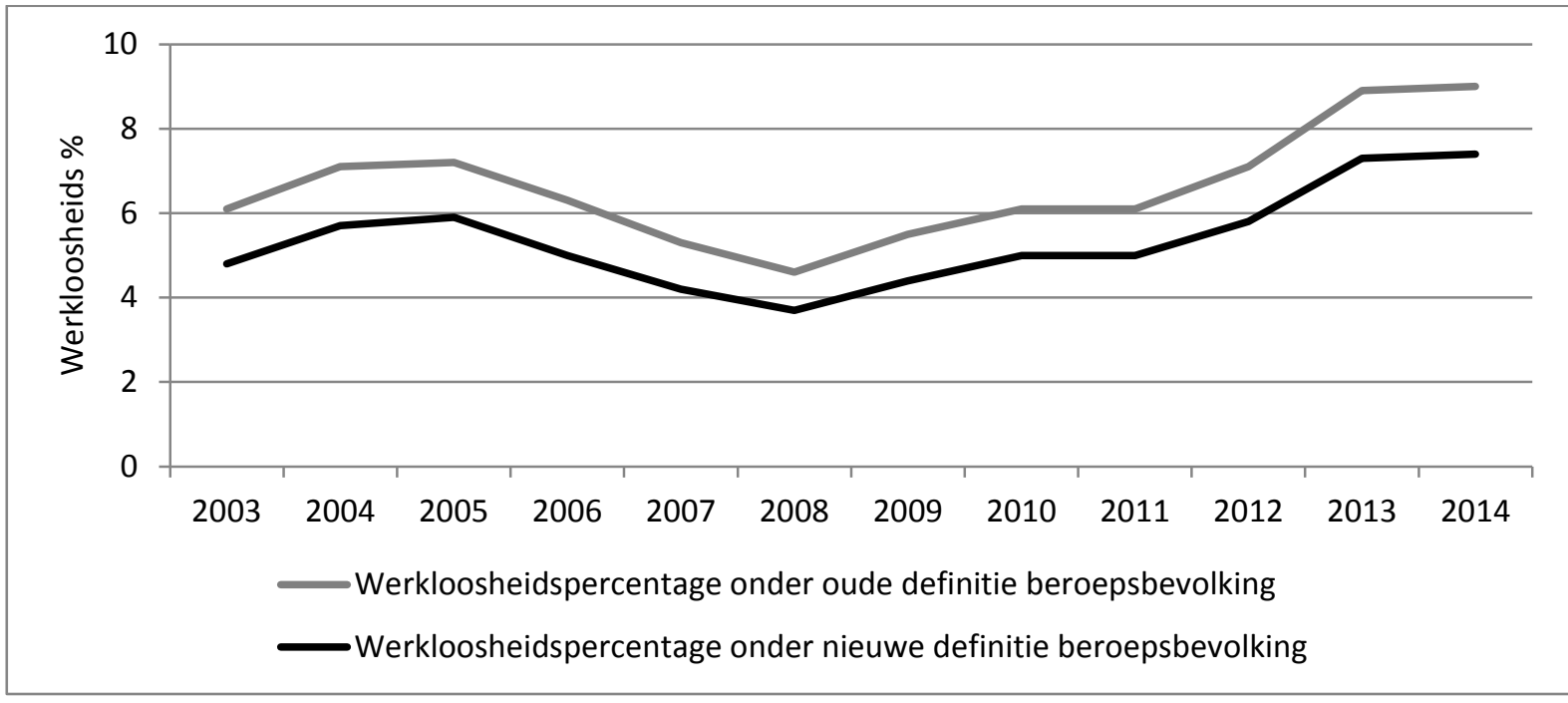




\subsection{Samenstelling van het aantal werkenden naar opleidingsniveau, leeftijd en geslacht}

Uit berekeningen op basis van de Enquête Beroepsbevolking (EBB) van het CBS blijkt dat er enkele opvallende veranderingen optreden in de samenstelling (naar leeftijd, geslacht en opleidingsniveau) van de werkzame beroepsbevolking als gevolg van de overstap op de nieuwe definitie van de beroepsbevolking. Deze veranderingen verschillen echter tussen de beroepsgroepen. In de analyses die hierna volgen wordt de samenstelling van de werkzame beroepsbevolking volgens de oude definitie vergeleken met de samenstelling onder de nieuwe definitie en komen verschillen tussen beroepsgroepen aan bod. Voor deze analyses is gebruik gemaakt van EBB-gegevens uit de jaren 2007-2011. Daarnaast is in de oude definitie van de beroepsbevolking uitgegaan van de leeftijdsgrenzen die het CBS ook hanteert bij de operationalisatie van de nieuwe definitie (15-74 i.p.v. 1564). Dit betekent dat verschillen in de samenstelling van de beroepsbevolking die het gevolg zijn van de overgang op de nieuwe leeftijdsgrens (van 15-64 jaar naar 16-74 jaar, zie figuur 1) niet worden meegenomen. De veranderingen in de opleidings- en geslachtssamenstelling binnen beroepsgroepen die het gevolg zijn van de overgang naar de nieuwe leeftijdsafbakening zijn namelijk minimaal en leiden voor de hier uitgevoerde analyses niet tot andere conclusies. ${ }^{13}$ Het feit dat de resultaten nauwelijks verschillen als het verschil in de gehanteerde leeftijdsgrens tussen de beide definities wél wordt meegenomen is het gevolg van het feit dat, ondanks de groei in arbeidsdeelname onder 65-plussers, hun aandeel in de werkzame beroepsbevolking (vooralsnog) beperkt blijft. ${ }^{14}$ Overigens dient te worden opgemerkt dat het niet meenemen van het verschil in leeftijdscriterium tussen beide definities een extra voordeel biedt voor de analyses in dit

\footnotetext{
${ }^{13}$ Ter illustratie: over de periode 2007-2011 neemt de omvang van de werkzame beroepsbevolking met ongeveer $13 \%$ toe als de nieuwe definitie van de beroepsbevolking wordt toegepast. Hiervan is slechts 1 procentpunt het resultaat van de overgang op de nieuwe leeftijdsafbakening. Ook in latere jaren, zoals in het meest recente jaar waarvoor data beschikbaar is (2014), maakt de toename in het aantal werkenden als gevolg van de nieuwe leeftijdsafbakening slechts een fractie van de totale toename in het aantal werkenden uit. Gezien deze relatief beperkte invloed van de verschuiving in leeftijdsafbakening is het niet verwonderlijk dat deze verschuiving geen substantiële invloed heeft op de conclusies in deze paragraaf.

${ }^{14}$ Het ROA onderzoekt momenteel samen met TNO de economische betekenis van de arbeidsdeelname van 65-plussers in een door Instituut GAK gefinancierd onderzoek.
} 
rapport. Een verruiming van de leeftijdsafbakening in de nieuwe definitie van de beroepsbevolking zou bij het onderzoeken van de impact van de nieuwe definitie op het aandeel ouderen immers op zichzelf per definitie al leiden tot een groeiend aandeel van deze groep in het totaal aantal werkenden.

Zoals figuur 2 liet zien is de omvang van de werkzame beroepsbevolking groter onder de nieuwe definitie van de beroepsbevolking. In figuren 4 tot en met 7 wordt onderzocht in welke mate de personen die onder de nieuwe definitie van de beroepsbevolking worden toegevoegd aan de werkzame beroepsbevolking verschillen van personen die al onderdeel uitmaakten van de werkzame beroepsbevolking onder de oude definitie. Hierbij wordt specifiek gekeken naar verschillen op het gebied van opleidingsniveau, leeftijd en geslacht.

\subsection{Opleidingsniveau werkenden}

Allereerst wordt gekeken naar het verschil in opleidingsniveau van de werkenden die al deel uitmaakten van de werkzame beroepsbevolking onder de oude definitie en het opleidingsniveau van de werkenden die onder de nieuwe definitie aan de werkzame beroepsbevolking worden toegevoegd.

Figuur 4 geeft het gemiddelde opleidingsniveau (GON) voor alle beroepsgroepen waar de werkzame beroepsbevolking met minimaal 10.000 personen toenam als gevolg van de overstap naar de nieuwe definitie van de beroepsbevolking. Het GON wordt berekend aan de hand van het aantal opleidingsjaren na het basisonderwijs, waarbij geldt dat er 3 jaar wordt geteld voor vmbo, 6 jaar voor havo, vwo en mbo, 9 jaar voor hbo en 12 jaar voor wo. ${ }^{15}$

Per beroepsgroep zijn in figuur 4 zowel het GON onder de oude definitie van de beroepsbevolking (horizontale as) als het GON van de personen die onder de nieuwe definitie worden toegevoegd aan de werkzame

\footnotetext{
${ }^{15}$ Zie Bijlsma, I., Dijksman, S., Fouarge D., \& Künn, A. (2015). Winnaars en verliezers op de arbeidsmarkt 1996-2012. Tijdschrift voor Arbeidsvraagstukken, (31)2, 106-123.
} 
beroepsbevolking (verticale as) weergeven. Elke cirkel representeert een beroepsgroep en de grootte van de cirkel geeft aan met hoeveel personen de werkzame beroepsbevolking toenam onder de nieuwe definitie van de beroepsbevolking. In de figuur is ook een 45-lijn opgenomen. Als een beroepsgroep op de 45--lijn ligt betekent dit dat er geen verschil is in het GON tussen werkenden die onder de nieuwe definitie worden toegevoegd aan de werkzame beroepsbevolking en de werkenden die onder de oude definitie al deel uitmaakten van de werkzame beroepsbevolking. Voor alle beroepsgroepen die onder de 45--lijn liggen geldt dat het GON lager is onder de groep personen die worden toegevoegd aan de werkzame beroepsbevolking, terwijl voor alle beroepsgroepen die boven de 45 -lijn liggen geldt dat het GON hoger is onder de groep werkenden die onder de nieuwe definitie worden toegevoegd aan de werkzame beroepsbevolking. ${ }^{16}$

Aangezien de meeste cirkels in figuur 4 iets onder de 450-lijn liggen kan worden geconcludeerd dat de werkende personen die onder de nieuwe definitie zijn toegevoegd aan de beroepsbevolking gemiddeld genomen over een lager opleidingsniveau beschikken. Dit lagere opleidingsniveau komt tot uiting in een GON van 4,8 voor de totale groep toegevoegde werkenden tegenover een GON van 6,5 voor de totale groep werkenden die onder de oude definitie al onderdeel uitmaakten van de beroepsbevolking. Als gevolg van het lagere opleidingsniveau van de groep toegevoegde werkenden daalt het GON van de werkzame beroepsbevolking onder de nieuwe definitie van een 6,5 naar een 6,3. Deze daling suggereert dat de groep werkenden die minder dan 12 uur per week werken voor een groot gedeelte uit scholieren en/of laag opgeleiden bestaat. Op deze groepen wordt later in dit rapport ingegaan.

16 Uiteraard neemt ook het gemiddelde opleidingsniveau toe (af) als een beroepsgroep zich in figuur 4 boven (beneden) de 450-lijn bevindt. De mate waarin dit gemiddelde verandert is naast de afstand van de 45 -lijn echter ook afhankelijk van de omvang van de groep werkenden die aan de werkzame beroepsbevolking wordt toegevoegd en de oorspronkelijke omvang van de betreffende beroepsgroep (d.w.z. de omvang onder de oude definitie van de werkzame beroepsbevolking). 


\section{Figuur 4}

Gemiddelde opleidingsniveau (GON) per beroepsgroep onder de oude en nieuwe definitie van de werkzame beroepsbevolking

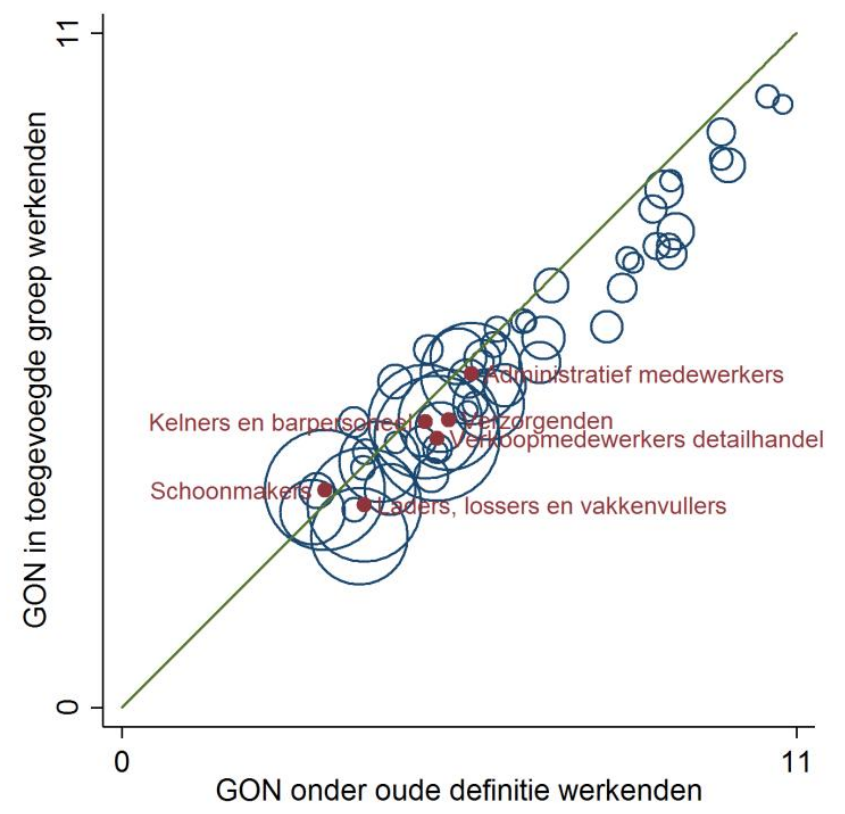

Bron: ROA (bewerking EBB)

Noot: In de figuur worden de zes beroepsgroepen waarvoor de absolute toename in het aantal werknemers het grootst is met naam aangeduid en zijn in het belang van de leesbaarheid enkel beroepsgroepen opgenomen die onder de nieuwe definitie minstens 10.000 extra werkenden erbij kregen

\subsection{Aandeel werkende 55-plussers}

In figuur 5 wordt per beroepsgroep het aandeel 55-plussers onder zowel de oude definitie van de werkzame beroepsbevolking als onder de personen die als gevolg van de nieuwe definitie worden toegevoegd aan de werkzame beroepsbevolking weergeven. Ook in deze figuur is een 45--lijn opgenomen waarop het aandeel 55-plussers onder de groep toegevoegde werkenden gelijk is aan het aandeel 55-plussers onder de oude definitie.

Het grootste gedeelte van de cirkels (beroepsgroepen) ligt boven de 45lijn, wat betekent dat het aandeel 55-plussers onder de groep toegevoegde werkenden hoger ligt $(18,4 \%)$ dan onder de personen die in de oude definitie al werden geclassificeerd als werkzaam (14,2\%). Tevens impliceert 
dit dat het aandeel 55-plussers onder de nieuwe definitie van de beroepsbevolking in de meeste beroepsgroepen toeneemt. Opvallend is dat de beroepsgroepen waar de absolute toename in het aantal werkenden het grootst is (weergeven door de grootste cirkels) over het algemeen dicht in de buurt van de 45 -lijn liggen en ongeveer even vaak boven als onder de 45--lijn liggen, terwijl de beroepsgroepen waar de toename in het aantal werkenden relatief beperkt is (de kleinste cirkels) vaak verder van de $45^{\circ}$ lijn vandaan liggen en vaker boven de 45o-lijn liggen dan eronder. De toename in het aandeel 55-plussers als gevolg van de nieuwe definitie van de beroepsbevolking concentreert zich dus voornamelijk op de beroepsgroepen waarbij de absolute toename in het aantal werkenden relatief beperkt is. ${ }^{17}$ Het aandeel ouderen in de werkzame beroepsbevolking neemt daardoor in totaal slechts beperkt toe, namelijk van $14,2 \%$ van de werkenden onder de oude definitie van de beroepsbevolking naar $14,6 \%$ onder de nieuwe definitie van de beroepsbevolking.

17 Deze conclusie wordt versterkt als ook beroepsgroepen waar de toename in het aantal werkenden lager is dan 10.000 worden meegenomen in de figuur. 


\section{Figuur 5}

Aandeel ouderen (55-plussers) per beroepsgroep onder de oude en nieuwe definitie van de werkzame beroepsbevolking

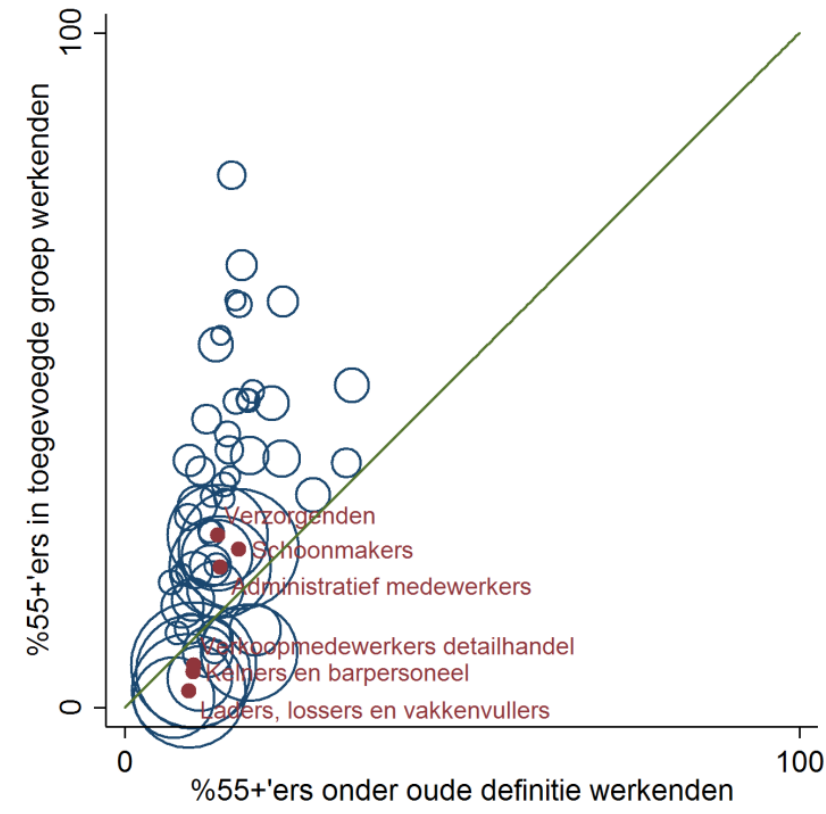

Bron: ROA (bewerking EBB)

Noot: In de figuur worden de zes beroepsgroepen waarvoor de absolute toename in het aantal werknemers het grootst is met naam aangeduid en zijn in het belang van de leesbaarheid enkel beroepsgroepen opgenomen die onder de nieuwe definitie minstens 10.000 extra werkenden erbij kregen

\subsection{Aandeel werkende jongeren}

Figuur 6 maakt duidelijk dat het aandeel werkende jongeren (d.w.z. het aandeel personen jonger dan 30 jaar) groter is onder de groep toegevoegde werkenden dan onder de groep werkenden die in de oude definitie van de beroepsbevolking al tot de werkenden werden gerekend. De cirkels, die voor elke beroepsgroep het aandeel jongeren dat onderdeel uitmaakt van het totaal aantal werkenden weergeven, zijn immers voornamelijk gelegen boven de 45 -lijn. Van de totale groep toegevoegde werkenden bestaat maar liefst $60 \%$ uit jongeren, tegenover 'slechts' $21,1 \%$ van groep personen die onder de oude definitie al als werkend werd geclassificeerd. Als gevolg hiervan stijgt het aandeel jongeren als onderdeel van de totale werkzame 
beroepsbevolking met 4,1 procentpunt, namelijk van $21,1 \%$ naar $25,2 \%$. Deze toename in het aandeel werkende jongeren is zowel een gevolg van een toename in het aandeel jonge mannen als een toename in het aandeel jonge vrouwen in de werkzame beroepsbevolking. Het toegenomen aandeel jonge vrouwen in de werkzame beroepsbevolking $1+2,4$ procentpunt) blijkt echter iets sterker bij te dragen aan deze groei dan het toegenomen aandeel jonge mannen ( $+1,6$ procentpunt). Dit laatste is ook zichtbaar aan het feit dat meer dan de helft (55\%) van de groep toegevoegde jongeren vrouw is.

In sommige gevallen, zoals bij de beroepsgroep laders, lossers en vakkenvullers, blijkt bijna de hele groep toegevoegde werkenden uit jongeren te bestaan waardoor het totale aandeel jongeren in deze specifieke beroepsgroep met 18 procentpunt toeneemt, namelijk van $41 \%$ naar $59 \%$. Bij de groep vuilnisophalers en dagbladenbezorgers stijgt het aandeel jongeren zelfs met 30 procentpunt, namelijk van $37 \%$ naar $67 \%$. Andere groepen waarvoor geldt dat de absolute toename in het aantal werkenden relatief hoog is en waarbij deze toename vooral bestaat uit jongeren zijn de groepen kelners en barpersoneel en de verkoopmedewerkers detailhandel. Gezien het feit dat de banen in deze groepen over het algemeen vaak als bijbaan door scholieren worden gekozen is het niet vreemd dat het aandeel jongeren in deze beroepsgroepen sterk toeneemt als personen met kleine banen ( $<12$ uur) ook worden gerekend tot de werkzame beroepsbevolking. 


\section{Figuur 6}

Aandeel jongeren (15-29 jarigen) per beroepsgroep onder de oude en nieuwe definitie van de werkzame beroepsbevolking

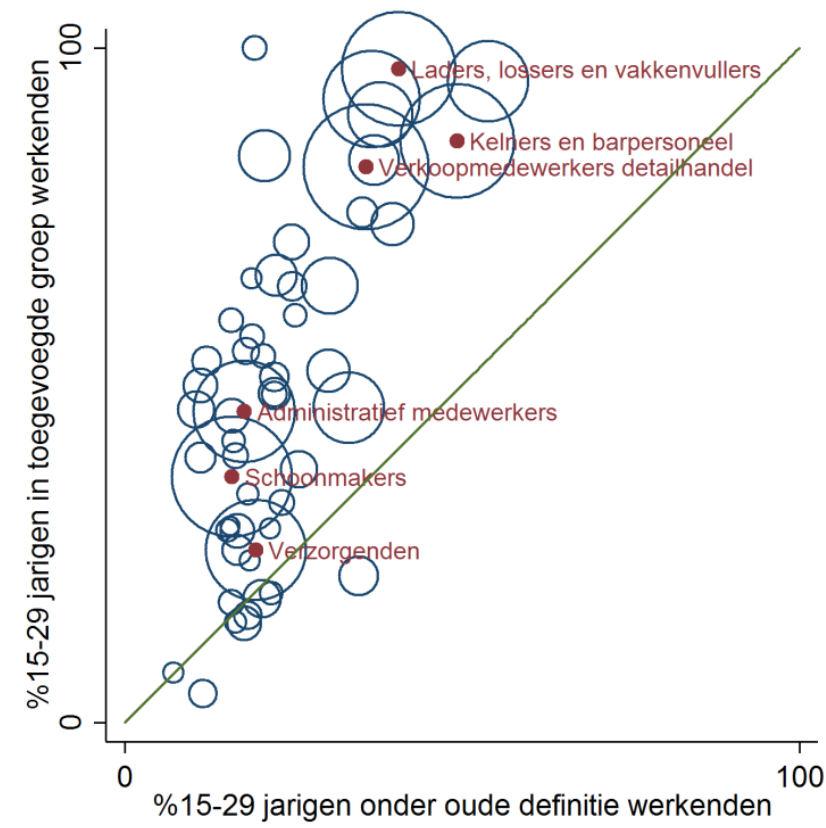

Bron: ROA (bewerking EBB)

Noot: In de figuur worden de zes beroepsgroepen waarvoor de absolute toename in het aantal werknemers het grootst is met naam aangeduid en zijn in het belang van de leesbaarheid enkel beroepsgroepen opgenomen die onder de nieuwe definitie minstens 10.000 extra werkenden erbij kregen

De sterke toename van het aandeel jongeren in bijbaantjes suggereert dat een groot gedeelte van de groep toegevoegde jongeren in figuur 6 uit scholieren/studenten bestaat. Om inzicht te verschaffen in de mate waarin de onder de nieuwe definitie toegevoegde groep jongeren uit scholieren/studenten bestaat, is in tabel 1 onder andere het percentage werkende jongeren met als maatschappelijke positie 'scholier/student' weergeven. De gegevens in deze tabel zijn gebaseerd op 2014 cijfers uit de Enquête Beroepsbevolking.

Van de groep werkenden jongeren die minstens 12 uur per week werkt, omschrijft $16,1 \%$ zijn of haar maatschappelijke positie als scholier/student. Van de groep werkende jongeren die minder dan 12 uur per week werken is dit met $88,5 \%$ een stuk hoger. Deze laatste groep is tevens de groep werkende jongeren die onder de nieuwe definitie van de beroepsbevolking 
wordt toegevoegd aan de al bestaande groep werkende jongeren. Met andere woorden: $88,5 \%$ van de groep jongeren die onder de nieuwe definitie wordt toegevoegd beschrijft zichzelf als scholier/student. Als gevolg hiervan stijgt het aandeel scholieren in de groep werkende jongeren van $16,1 \%$ onder de oude definitie naar $37,2 \%$ onder de nieuwe definitie. De impact van scholieren/studenten is overigens ook zichtbaar als we kijken naar de totale werkzame beroepsbevolking (d.w.z. zonder onderscheid naar leeftijdsklassen). Beschrijft onder de oude definitie slechts 3,3\% van de werkenden zichzelf als scholier/student, onder de groep toegevoegde werkenden is dit meer dan de helft $(54,9 \%)$, waardoor het aandeel scholieren/studenten onder de nieuwe definitie toeneemt tot 9,4\%.

\section{Tabel 1}

Aantal werkenden en percentage scholieren/studenten, 2014

\begin{tabular}{|c|c|c|c|}
\hline & \multicolumn{3}{|c|}{ Aantal uren werk } \\
\hline & $<12$ uur & $\geq 12$ uur & $\geq 1$ uur \\
\hline & $\begin{array}{r}=\text { 'kleine } \\
\text { banen' }\end{array}$ & $\begin{array}{r}=\text { oude } \\
\text { definitie }\end{array}$ & $\begin{array}{r}=\text { nieuwe } \\
\text { definitie }\end{array}$ \\
\hline Totaal aantal werkende jongeren (15-29) & 595.500 & 1.449 .000 & 2.044 .000 \\
\hline Waarvan \% met positie scholier/student & $88,5 \%$ & $16,1 \%$ & $37,2 \%$ \\
\hline Totaal aantal werkenden (15-74) & 971.000 & 7.243 .000 & 8.214 .000 \\
\hline Waarvan \% met positie scholier/student & $54,9 \%$ & $3,3 \%$ & $9,4 \%$ \\
\hline
\end{tabular}

\subsection{Aandeel werkende vrouwen}

Zoals figuur 7 laat zien is het aandeel vrouwen onder de groep toegevoegde werkenden in bijna alle beroepsgroepen groter dan onder de groep werkenden die in de oude definitie al werden geclassificeerd als werkzaam. In de totale groep toegevoegde werkenden zonder onderscheid naar beroepsgroep is het percentage vrouwen met $63,1 \%$ daardoor dan ook een stuk hoger dan onder de groep personen die onder de oude definitie al 
werd geclassificeerd als werkzaam (43,2\%). Gezien het grote aantal vrouwen dat in deeltijd werkt is dit niet vreemd. ${ }^{18}$ Als gevolg van het hogere percentage vrouwen in de toegevoegde groep werkenden stijgt het percentage vrouwen als onderdeel van het totaal aantal werkenden met iets meer dan 2 procentpunt, namelijk van 43,2\% naar 45,4\%. Binnen de specifieke beroepsgroepen varieert dit van een daling van maximaal 9 procentpunt in het aandeel vrouwen voor de beroepsgroep keukenhulpen tot een stijging van maximaal 9,2 procentpunt voor de beroepsgroep vuilnisophalers en dagbladenbezorgers. Voor sommige beroepsgroepen, zoals verzorgenden en schoonmakers, geldt weliswaar dat bijna $100 \%$ van de personen die erbij komen door de nieuwe definitie van de beroepsbevolking vrouw zijn, maar gezien het feit dat in deze beroepsgroepen al voornamelijk vrouwen werkzaam waren is het niet vreemd dat dit percentage ook erg hoog is onder de groep toegevoegde werkenden. Het totale aandeel vrouwen verandert in deze beroepsgroepen dan ook nauwelijks.

\footnotetext{
8 In 2014 had 75\% van de vrouwen die onderdeel uitmaakten van de werkzame beroepsbevolking deeltijdwerk (gedefinieerd als gemiddeld minder dan 35 uur betaald werk per week) tegenover 26\% van de mannen (CBS Statline). Voor eerdere jaren, waaronder ook de jaren 2007-2011 (waarop de figuren 4-7), is aandeel vrouwen dat deeltijd werkt in verhouding tot het aandeel mannen dat deeltijd werkt zelfs nog iets hoger.
} 


\section{Figuur 7}

Aandeel vrouwen per beroepsgroep onder de oude en nieuwe definitie van de werkzame beroepsbevolking

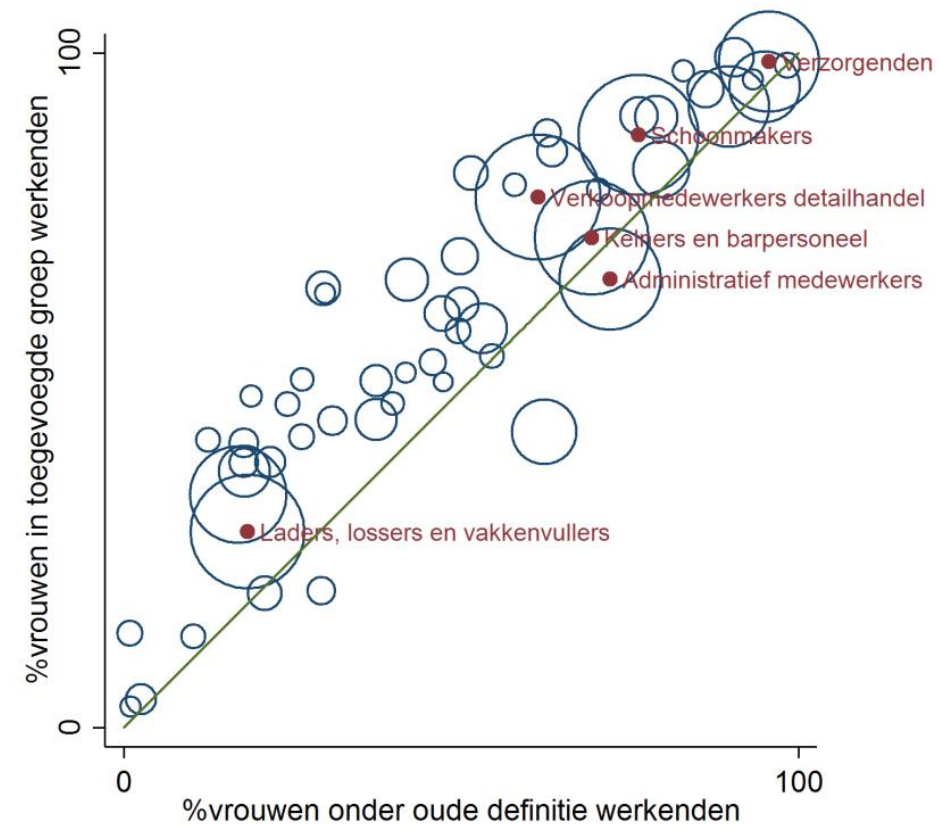

Bron: ROA (bewerking EBB)

Noot: In de figuur worden de zes beroepsgroepen waarvoor de absolute toename in het aantal werknemers het grootst is met naam aangeduid en zijn in het belang van de leesbaarheid enkel beroepsgroepen opgenomen die onder de nieuwe definitie minstens 10.000 extra werkenden erbij kregen

\subsection{Beroepsgroepen met sterkste toename in aantal werkenden}

Tabel 2 geeft een overzicht van de 10 beroepsgroepen waarbij het aantal werkenden (d.w.z. de werkzame beroepsbevolking) het sterkst toeneemt als gevolg van de overgang naar de nieuwe definitie van de beroepsbevolking. Voor alle beroepsgroepen die in de top 10 voorkomen geldt dat er meer dan 100.000 werkenden bij komen onder de nieuwe definitie. Het verschil in aantal werkenden tussen de oude en nieuwe definitie is het grootst bij de verkoopmedewerkers detailhandel. In deze beroepsgroep kwamen er maar liefst 437.000 werkenden bij onder de nieuwe definitie van de beroepsbevolking. Ook bij de schoonmakers komen er meer dan 400.000 mensen bij. Als we kijken naar de samenstelling van 
de top 10 valt op dat er o.a. sprake is van een grote groei in typische bijbanen voor jongeren (bijvoorbeeld vakkenvullers en kassamedewerkers).

Naast het totaal aantal werkenden geeft tabel 2 ook het GON per beroepsgroep weer. De verschillen in het GON tussen de oude en nieuwe definitie blijven in de meeste gevallen relatief beperkt. Het grootste verschil is zichtbaar bij de groep vuilnisophalers en dagbladenbezorgers. In deze groep neemt het GON met 0,7 jaar af onder de nieuwe definitie van de werkzame beroepsbevolking. Bij de overige opleidingsgroepen uit tabel 2 ligt het verschil in de GON telkens tussen de $+0,1$ en de -0,3 opleidingsjaren. Het aandeel werknemers van 55 jaar of ouder neemt in sommige beroepsgroepen toe en in andere af, terwijl het aandeel werknemers dat jonger dan 30 jaar is binnen alle in de top 10 opgenomen beroepsgroepen toeneemt. Ook zijn de verschuivingen in de groep jongeren $(\leq 30)$ over het algemeen veel groter dan de verschuivingen in de groep ouderen (55plussers); zo neemt het aandeel jongeren in de groep vuilnisophalers en dagbladenbezorgers met maar liefst 30 procentpunt toe, terwijl het aandeel ouderen in deze beroepsgroep met 6,3 procentpunt daalt als gevolg van de nieuwe definitie van de beroepsbevolking. Als we kijken naar de man-vrouwverhouding valt op dat het aandeel vrouwen sterk toeneemt in de groep vuilnisophalers en dagbladenbezorgers ( $+9,3$ procentpunt), terwijl een sterke daling van het aandeel vrouwen is te zien bij de keukenhulpen (-9 procentpunt).

De in tabel 2 weergeven top 10 van beroepsgroepen met de sterkste stijging in het totaal aantal werkenden is gebaseerd op absolute aantallen werkenden. Dit betekent dat er geen rekening wordt gehouden met de oorspronkelijke omvang van de werkzame beroepsbevolking van de betreffende beroepsgroepen (d.w.z. de omvang van het aantal werkenden onder de oude definitie van de beroepsbevolking). Uiteraard is het ook mogelijk te kijken naar de vraag waar het aantal werkenden relatief het sterkst steeg onder de nieuwe definitie. Bijlage $A$ toont daarom de top 10 beroepsgroepen met de sterkste procentuele toename in het aantal werkenden. De beroepsgroepen die zijn opgenomen in de top 10 van tabel 2 komen in zeven van de tien gevallen overeen met beroepsgroepen die zijn opgenomen in Bijlage A. Wel zijn er duidelijke verschillen in rangorde tussen de tabellen. Zo kent de groep vuilnisophalers en dagbladenbezorgers de sterkste procentuele toename in het aantal werkenden (bijna 2,5 keer 
zoveel werkenden onder de nieuwe definitie), maar zijn er zes beroepsgroepen die in absolute aantallen een sterkere toename in het aantal werkenden kennen.

\section{Tabel 2}

Top 10 beroepsgroepen met de grootste toename in het aantal werkenden als gevolg van de overgang op de nieuwe definitie van de beroepsbevolking

\begin{tabular}{|c|c|c|c|}
\hline & Oude definitie & Nieuwe definitie & Verschil \\
\hline \multicolumn{4}{|c|}{ Verkoopmedewerkers detailhandel } \\
\hline \# werkenden & 1.616 .000 & 2.053 .000 & 437.000 \\
\hline GON & 5,1 & 5 & $-0,1$ \\
\hline$\% 55+$ & 10,2 & 9,4 & $-0,8$ \\
\hline$\% 30-$ & 35,8 & 45,7 & 9,9 \\
\hline$\%$ vrouw & 61,4 & 65,1 & 3,7 \\
\hline \multicolumn{4}{|l|}{ Schoonmakers } \\
\hline \# werkenden & 781.000 & 1.188 .500 & 407.500 \\
\hline GON & 3,3 & 3,4 & 0,1 \\
\hline$\% 55+$ & 16,9 & 19 & 2,1 \\
\hline$\% 30-$ & 15,9 & 22,7 & 6,8 \\
\hline$\%$ vrouw & 76,3 & 79,5 & 3,2 \\
\hline \multicolumn{4}{|l|}{ Kelners en barpersoneel } \\
\hline \# werkenden & 625.000 & 988.000 & 363.000 \\
\hline GON & 5 & 4,8 & $-0,2$ \\
\hline$\% 55+$ & 10,1 & 8,3 & $-1,8$ \\
\hline$\% 30-$ & 49,3 & 62,6 & 13,3 \\
\hline$\%$ vrouw & 69,4 & 70,3 & 0,9 \\
\hline \multicolumn{4}{|c|}{ Laders, lossers en vakkenvullers } \\
\hline \# werkenden & 733.500 & 1.095 .500 & 362.000 \\
\hline GON & 4 & 3,7 & $-0,3$ \\
\hline$\% 55+$ & 9,5 & 7,2 & $-2,3$ \\
\hline$\% 30-$ & 40,6 & 58,9 & 18,3 \\
\hline$\%$ vrouw & 18,4 & 21,8 & 3,4 \\
\hline \multicolumn{4}{|c|}{ Administratief medewerkers } \\
\hline \# werkenden & 1.875 .500 & 2.164 .000 & 288.500 \\
\hline GON & 5,7 & 5,7 & 0 \\
\hline$\% 55+$ & 14,2 & 15 & 0,8 \\
\hline$\% 30-$ & 17,7 & 21,4 & 3,7 \\
\hline$\%$ vrouw & 72,1 & 71,2 & $-0,9$ \\
\hline \multicolumn{4}{|l|}{ Verzorgenden } \\
\hline \# werkenden & 1.094 .000 & 1.378 .500 & 284.500 \\
\hline GON & 5,3 & 5,2 & $-0,1$ \\
\hline$\% 55+$ & 13,8 & 16,1 & 2,3 \\
\hline$\% 30-$ & 19,5 & 20,6 & 1,1 \\
\hline$\%$ vrouw & 95,7 & 95,9 & 0,2 \\
\hline \multicolumn{4}{|c|}{ Vuilnisophalers en dagbladenbezorgers } \\
\hline \# werkenden & 181.000 & 442.500 & 261.500 \\
\hline GON & 3,9 & 3,2 & $-0,7$ \\
\hline$\% 55+$ & 18,4 & 12,1 & $-6,3$ \\
\hline$\% 30-$ & 36,6 & 66,6 & 30 \\
\hline$\%$ vrouw & 17 & 26,3 & 9,3 \\
\hline
\end{tabular}




\begin{tabular}{crrr}
\hline Tabel 2, vervolg & Oude definitie & Nieuwe definitie & Verschil \\
\hline Kassamedewerkers & & & \\
\# werkenden & 266.000 & 450.000 & 184.000 \\
GON & 4,2 & 4,1 & $-0,1$ \\
\% 55+ & 7,4 & 4,9 & $-2,5$ \\
\% 30- & 53,8 & 70,4 & 16,6 \\
\% vrouw & 89,7 & 90,4 & 0,7 \\
\# werkenden & & & \\
GON & 544.500 & 683.500 & 139.000 \\
\% 55+ & 6 & 5,8 & $-0,2$ \\
\% 30- & 13,7 & 15,4 & 1,7 \\
\% vrouw & 33,3 & 35,8 & 2,5 \\
Leidsters kinderopvang en onderwijsassistenten & 95 & 94,6 & $-0,4$ \\
\# werkenden & & & 115.500 \\
GON & 135.500 & 251.000 & 0 \\
\% 55+ & 3,1 & 3,1 & $-3,2$ \\
\% vrouw & 11,2 & 81 & 23,1 \\
Keukenhulpen & 37,9 & 53,3 & -9 \\
\hline
\end{tabular}

Bron: ROA (bewerking EBB)

Noot: In totaal worden in de Beroepenindeling ROA/CBS 114 verschillende beroepsgroepen onderscheiden 
Vanaf 2015 hanteert het CBS de internationale ILO-definitie voor het meten van de omvang van de beroepsbevolking. De voornaamste verschillen tussen de oude en de nieuwe definitie van de beroepsbevolking hebben betrekking op het aantal uren dat iemand werkt of wil werken en de door het CBS gehanteerde leeftijdsgrens. In de oude definitie gold een urencriterium van minimaal 12 uur werk per week en werd in de praktijk een leeftijdsgrens van 15 tot en met 64 jaar gehanteerd, terwijl in de nieuwe definitie een urencriterium van minimaal 1 uur per week geldt en in de praktijk een leeftijdsgrens van 15 tot en met 74 jaar door het CBS wordt gehanteerd. De nieuwe definitie van de beroepsbevolking zal ook gebruikt worden in het rapport De arbeidsmarkt naar opleiding en beroep tot 2020.

Er zijn twee belangrijke redenen om over te stappen op de nieuwe definitie van de beroepsbevolking. In de eerste plaats levert de overstap op de nieuwe definitie cijfers op die in internationaal perspectief beter vergelijkbaar zijn (de ILO-definitie van de beroepsbevolking geldt als internationale standaard). Bovendien wordt in de nieuwe definitie van de beroepsbevolking ook de groep 65-74 jarigen meegenomen, een groep personen die gezien de verhoogde AOW-leeftijd in toenemende mate zal deelnemen aan de arbeidsmarkt.

Voor wat betreft de ontwikkeling van het aantal werkenden, het aantal werklozen en het werkloosheidspercentage over tijd leveren beide definities van de beroepsbevolking (ongeveer) hetzelfde beeld op. Als een van deze variabelen in de ene definitie stijgt of daalt, gaat dit immers vrijwel altijd gepaard met eenzelfde (en vaak bijna proportionele) beweging in deze variabele volgens de andere definitie. De beide definities van de beroepsbevolking leveren echter niet hetzelfde beeld op voor wat betreft de omvang van de beroepsbevolking, het aantal werkenden, het aantal werklozen en de hoogte van het werkloosheidspercentage. Het aantal werkenden valt onder de nieuwe definitie van de beroepsbevolking hoger uit, terwijl het aantal werklozen en het werkloosheidspercentage onder de nieuwe definitie juist lager uitvallen.

Als de groep werkenden onder de oude definitie van de beroepsbevolking wordt vergeleken met de groep werkenden onder de nieuwe definitie van 
de beroepsbevolking terwijl veranderingen die het gevolg zijn van een overstap op de nieuwe leeftijdsgrens buiten beschouwing worden gelaten, blijkt dat er enkele opvallende verschillen optreden in de samenstelling van de werkzame beroepsbevolking. De personen die onder de nieuwe definitie van de beroepsbevolking worden toegevoegd aan de groep werkenden blijken gemiddeld genomen bijvoorbeeld over een lager opleidingsniveau te beschikken. Dit sluit aan bij de bevinding dat de groep toegevoegde werkenden voor een groot gedeelte uit jongeren (d.w.z. jonger dan 30 jaar) en scholieren/studenten bestaat. Zo bestaat $60 \%$ van de toegevoegde groep werkenden uit jongeren, tegenover 'slechts' $21,1 \%$ van de groep personen die onder de oude definitie al als werkend werden geclassificeerd. In sommige beroepsgroepen, bijvoorbeeld bij de laders, lossers en vakkenvullers, bleek zelfs bijna de hele groep toegevoegde werkenden uit jongeren te bestaan.

Naast het aandeel jongeren, blijkt dat ook het aandeel 55-plussers en het aandeel vrouwen onder de nieuwe definitie van de beroepsbevolking toeneemt. De stijging in het aandeel vrouwen is consistent met het relatief hoge aandeel vrouwen dat in deeltijd werkt en de bevinding dat de toegevoegde groep jongeren voor het grootste gedeelte ook uit vrouwen bestaat. Het aandeel ouderen blijkt binnen de meeste beroepsgroepen toe te nemen, maar doordat deze toename zich voornamelijk concentreert in de beroepsgroepen waar de absolute toename in het aantal werkenden beperkt blijft, leidt dit tot een relatief beperkte stijging van het aandeel ouderen in de totale beroepsbevolking (van 14,2\% naar 14,6\%).

Het aantal toegevoegde werkenden in de tien beroepsgroepen met de grootste absolute stijging in het aantal werkenden bleek te variëren van +115.500 tot +437.000 . De absolute toename in het aantal werkenden bleek het grootst in de beroepsgroep verkoopmedewerkers detailhandel terwijl de procentuele toename in het aantal werkenden het grootst bleek in de beroepsgroep vuilnisophalers en dagbladenbezorgers (bijna 2,5 keer zoveel werkenden onder de nieuwe definitie). In het algemeen bleken beroepsgroepen met bijbanen de sterkste stijging in het aantal werkenden (zowel in absolute als in relatieve termen) te laten zien, bij de overgang van de nationale naar de internationale definitie. 


\section{Bijlage A}

Top 10 beroepsgroepen met de grootste procentuele toename in het aantal werkenden als gevolg van de overgang op de nieuwe definitie van de beroepsbevolking

\begin{tabular}{|c|c|c|c|}
\hline & Oude definitie & Nieuwe definitie & Verschil \\
\hline \multicolumn{4}{|c|}{ Vuilnisophalers en dagbladenbezorgers } \\
\hline \# werkenden & 181.000 & 442.500 & $\times 2,4$ \\
\hline GON & 3,9 & 3,2 & $-0,7$ \\
\hline$\% 55+$ & 18,4 & 12,1 & $-6,3$ \\
\hline$\% 30-$ & 36,6 & 66,6 & 30 \\
\hline \% vrouw & 17 & 26,3 & 9,3 \\
\hline \multicolumn{4}{|l|}{ Keukenhulpen } \\
\hline \# werkenden & 135.500 & 251.000 & $\times 1,9$ \\
\hline GON & 3,1 & 3,1 & 0 \\
\hline$\% 55+$ & 11,2 & 8 & $-3,2$ \\
\hline$\% 30-$ & 37,9 & 61 & 23,1 \\
\hline$\%$ vrouw & 62,3 & 53,3 & -9 \\
\hline \multicolumn{4}{|l|}{ Kassamedewerkers } \\
\hline \# werkenden & 266.000 & 450.000 & $\times 1,7$ \\
\hline GON & 4,2 & 4,1 & $-0,1$ \\
\hline$\% 55+$ & 7,4 & 4,9 & $-2,5$ \\
\hline$\% 30-$ & 53,8 & 70,4 & 16,6 \\
\hline \% vrouw & 89,7 & 90,4 & 0,7 \\
\hline \multicolumn{4}{|l|}{ Hulpkrachten landbouw } \\
\hline \# werkenden & 30.000 & 47.500 & $\times 1,6$ \\
\hline GON & 3,8 & 3,6 & $-0,2$ \\
\hline$\% 55+$ & 13,3 & 10,9 & $-2,4$ \\
\hline$\% 30-$ & 19,2 & 42,8 & 23,6 \\
\hline$\%$ vrouw & 54,6 & 50,9 & $-3,7$ \\
\hline \multicolumn{4}{|l|}{ Kelners en barpersoneel } \\
\hline \# werkenden & 625.000 & 988.000 & $\times 1,6$ \\
\hline GON & 5 & 4,8 & $-0,2$ \\
\hline$\% 55+$ & 10,1 & 8,3 & $-1,8$ \\
\hline$\% 30-$ & 49,3 & 62,6 & 13,3 \\
\hline$\%$ vrouw & 69,4 & 70,3 & 0,9 \\
\hline \multicolumn{4}{|l|}{ Schoonmakers } \\
\hline \# werkenden & 781.000 & 1.188 .500 & $\times 1,5$ \\
\hline GON & 3,3 & 3,4 & 0,1 \\
\hline$\% 55+$ & 16,9 & 19 & 2,1 \\
\hline$\% 30-$ & 15,9 & 22,7 & 6,8 \\
\hline$\%$ vrouw & 76,3 & 79,5 & 3,2 \\
\hline \multicolumn{4}{|c|}{ Laders, lossers en vakkenvullers } \\
\hline \# werkenden & 733.500 & 1.095 .500 & $\times 1,5$ \\
\hline GON & 4 & 3,7 & $-0,3$ \\
\hline$\% 55+$ & 9,5 & 7,2 & $-2,3$ \\
\hline$\% 30-$ & 40,6 & 58,9 & 18,3 \\
\hline$\%$ vrouw & 18,4 & 21,8 & 3,4 \\
\hline
\end{tabular}


Bijlage A, vervolg Sportinstructeurs

$\begin{array}{lrrr}\text { \# werkenden } & 111.000 & 163.000 & \times 1,5 \\ \text { GON } & 6,2 & 5,9 & -0,3 \\ \text { \% 55+ } & 8,6 & 10,1 & 1,5 \\ \text { \% 30- } & 39,7 & 48 & 8,3 \\ \text { \% vrouw } & 42 & 47,5 & 5,5\end{array}$

Callcentermedewerkers outbound en overige verkopers

\begin{tabular}{lrrr} 
\# werkenden & 194.500 & 263.500 & $\times 1,4$ \\
GON & 5,2 & 5 & $-0,2$ \\
\% 55+ & 12,4 & 11,2 & $-1,2$ \\
\% 30- & 37 & 48,2 & 11,2 \\
\% vrouw & 53,1 & 54 & 0,9 \\
medewerkers detailhandel & & & \\
\# werkenden & 1.616 .000 & 2.053 .000 & $\times 1,3$ \\
GON & 5,1 & 5 & $-0,1$ \\
\% 55+ & 10,2 & 9,4 & $-0,8$ \\
\% 30- & 35,8 & 45,7 & 9,9 \\
\% vrouw & 61,4 & 65,1 & 3,7 \\
\hline
\end{tabular}

Bron: ROA (bewerking EBB)

Noot: In totaal worden er in de EBB 114 verschillende beroepsgroepen onderscheiden 